\title{
Nemoptera sinuata Olivier, 1811 (Neuroptera: Nemopteridae) - old new record for Russia
}

\section{Nemoptera sinuata Olivier, 1811 (Neuroptera: Nemopteridae) - старое новое указание дия фауны России}

\author{
Roland Dobosz ${ }^{1}$, Victor A. Krivokhatsky ${ }^{2}$ \\ Ролан Аобош ${ }^{1}$, Виктор А. Кривохатский ${ }^{2}$
}

\footnotetext{
${ }^{1}$ Upper Silesian Museum, Natural History Department, P1. Sobieskiego 2, 41-902 Bytom, Poland. E-mail: dobosz@muzeum.bytom.pl

${ }^{2}$ Zoological Institute, Russian Academy of Sciences, St. Petersburg 199034 Russia. E-mail: krivokhatsky@yandex.ru

2 Зоологический институт РАН, Университетская наб. 1, Санкт-Петербург 199034, Россия.
}

KEY WORDS. Nemopteridae, Nemoptera sinuata, distribution, Russia, North Ossetia, regionally extinct species.

КЛЮЧЕВЫЕ СЛОВА. Нитекрылки, Nemoptera sinuata, распределение, Россия, Северная Осетия, регионально вымерший вид.

ABSTRACT. Old specimen (male) of Nemoptera sinuata Olivier, 1811 was found in the collection of Zoological Institute in St. Petersburg. It was collected by P.V. Nesterov in Kaban village (modern Koban village, Nord Ossetia-Alania, Russia) during his expedition in Olty part [recently Caucasian] of Karsk Region of Russian Imperia in 1910. This finding was published in earlier publication [Alexandrov-Martynov, 1930; Makarjan, 1930], but was not recorded for the distribution of $N$. sinuata in Russia in modern boundaries [Aspöck et al., 2001]. This is the northern locality in the species distribution area. However, new records did not known in Ossetia during later century.

РЕЗЮМЕ. В колЛекции Зоологического института РАН в Петербурге обнаружен единственный самец Nemoptera sinuata Olivier, 1811, собранный П.В. Нестеровым во время экспедиции в Ольтскую провинцию (ныне Кавказ) Карской области Российской Империи в 1910 г. Эта находка была опубликована ранее [Alexandrov-Martynov, 1930; Makarjan, 1930], но не была учтена для фауны современной России [Aspöck et al., 2001]. Это самое северная точка ареала $N$. sinuata. Однако за последнее столетие новых находок на территории Осетии не известно.

In the old collection of Nemopteridae of Zoological Institute of Russian Academy of Science (ZISP), preserved since the time when O.M. Martynova has been a curator, one male of Nemoptera sinuata Olivier, 1811 with the labels "Kaban vil. env., Olty distr.,
Karsk Reg., 1910, Nesterov", and "Nemoptera sinuata Ol., Alexandrova-Mart. det." was found. This male (Fig. 1) has no distinctions from Armenian and Turkish specimens in the collection of ZISP, and different from them by size only: fore wing length $-22 \mathrm{~mm}$, hind wing length $-37 \mathrm{~mm}$ (one of Armenian specimen has $39 \mathrm{~mm}$ and $55 \mathrm{~mm}$, correspondingly).

The found by us specimen has been mentioned earlier in the revision of Nemopteridae of Persia and adjacent countries by O.M. Martynova [AlexandrovMartynov, 1930] as a female. Moreover two another females from Kreis, also from "Olty distr., Karsk Reg., 1910, Nesterov coll." were indicated in this paper. However, these last specimens are absent in the collection of ZISP and their particular locality is unknown. It could situate in any territories of Osetia, Georgia or neighboring countries - in ancient Oltyn part of Karsk Region of ancient Russian Empery. Other specimens of $N$. sinuata were collected by P.V. Nesterov in close locality — "Koban' vil. Olor vil., 6.VII.1909". This finding is mentioned in the list of Makarian [1930] with refer to the report of K.M. Deriugin.

Among these localities only Kaban [Koban] village can attribute to modern Nord Ossetia-Alania (Russia). This is extremely northern locality of species distribution (Fig. 2), which has no confirmation on species survival last century. In the last catalogue of Western Palaearctic Neuroptera [Aspöck et al., 2001] $N$. sinuata was not recorded from Russia, and therefore, our specimen is the old new record for the Russian fauna. There are no new registrations of $N$. sinua-

How to cite this article: Dobosz R., Krivokhatsky V.A. 2019. Nemoptera sinuata Olivier, 1811 (Neuroptera: Nemopteridae) — old new record for Russia // Russian Entomol. J. Vol.28. No.1. P.64-65. doi: 10.15298/ rusentj.28.1.09 
ta in Ossetia during last century, so that we attribute this species to the category 'Regionally Extinct'.

ACKNOWLEDGEMENTS. We would like to express special thanks to Anna Khalina (library of ZIN) for the help in getting the copy from the old annual and to Waldemar Żyła (Natural History Department of USMB) for preparing the map. The study was performed in the frames of the state research project AAAA-A171170303102059 and supported by the Presidium RAS program No. 41 "Biodiversity of natural systems and biological sources of Russia”.

\section{References}

Alexandrov-Martynov O.M. 1930. Zur Kenntnis der Nemopteriden Persiens und einiger Mittelmeerlander // Zoologischer Anzeiger. Bd. 90. Hf.9/12. S.235-250.

Aspöck H., Hölzel H., Aspöck U. 2001. Kommentierter katalog der Neuropterida (Insecta: Raphidioptera, Megaloptera, Neuroptera) der Westpaläarktis // Denisia. Bd.02. S.1-606.

Makarian M.J. 1930. [New data on distribution of some representativities of the family Nemopteridae (Neuroptera) in Transkaukasia] // [Zakavkazskyi kraevedtcheskyi sbornik]. Ser. A. Natural history. Bd.I. Tiflis. P.145-148 [in Russian, with English summary].

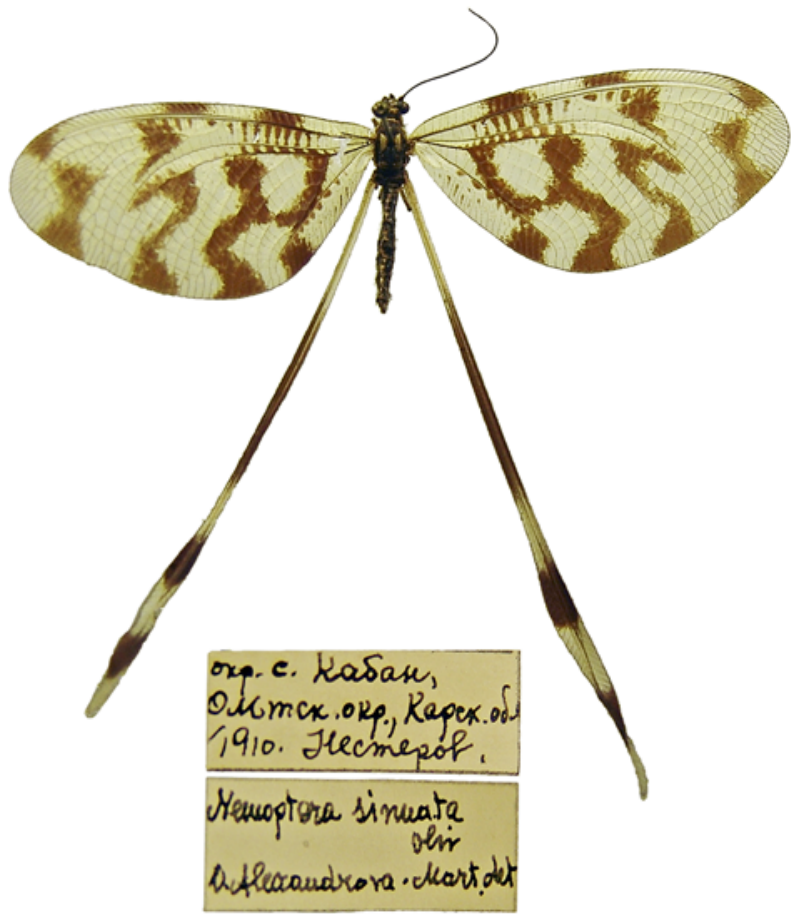

Fig. 1. Collection specimen of Nemoptera sinuata.

Рис. 1. Коллекционный экземпляр Nemoptera sinuata.

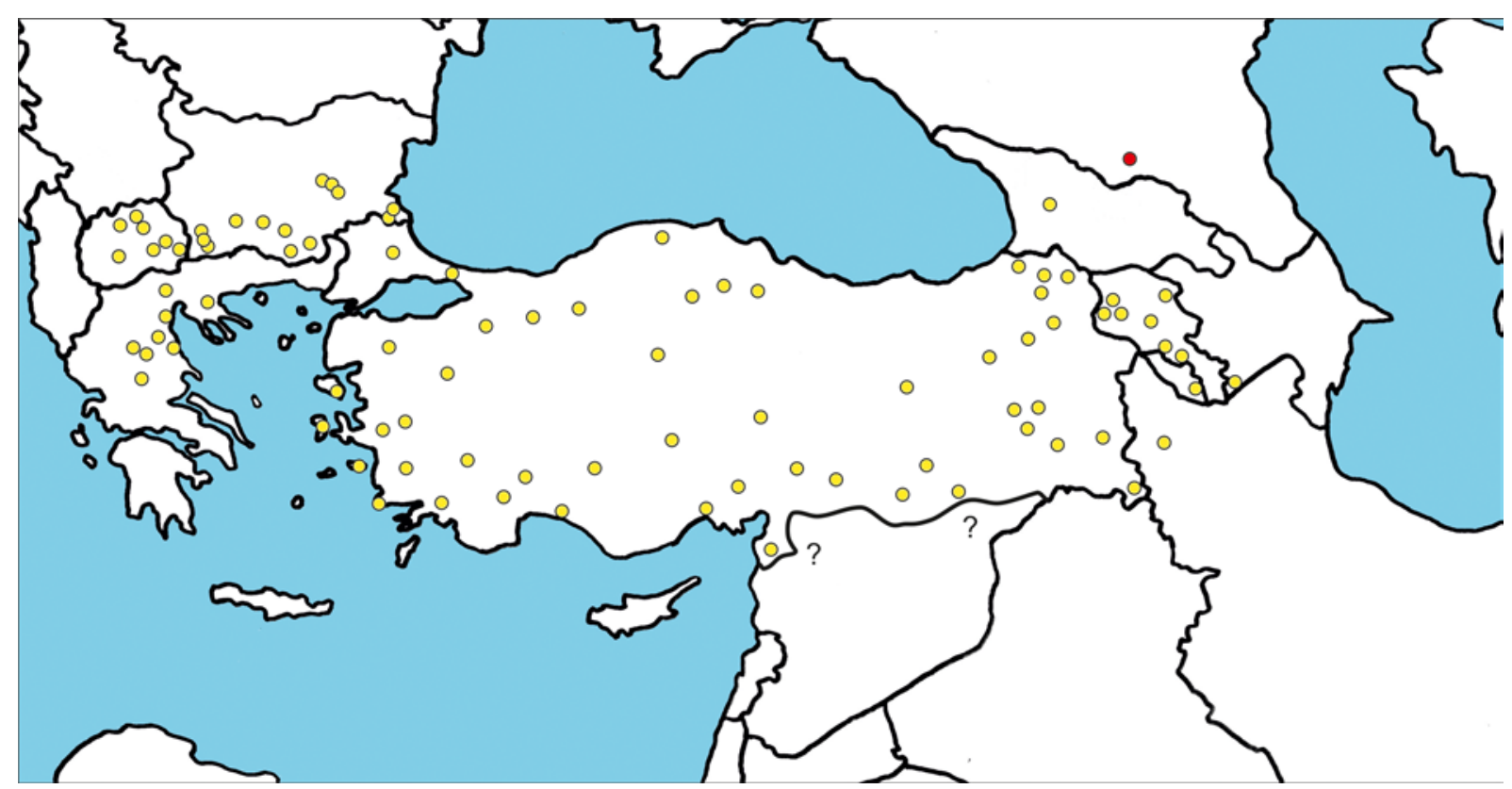

Fig. 2. Distribution map of Nemoptera sinuata: yellow circle — bibliographic data; red circle - Koban vill.

Рис. 2. Карта распространения Nemoptera sinuata: жёлтые точки - литературные данные; красная точка — c. Кобан. 